\title{
Depression Expressions in Selected English and Kurdish Poems
}

\author{
Bahar Assi Amin \\ Department of English, College of Education, University of Garmian
}

\section{Article Info \\ Received: October, 2019 \\ Revised:October,2019 \\ Accepted:November,2019 \\ Keywords}

Depression, Kurdish Poems , English Poems

Corresponding Author

baharhb.2008@gmail.com

\begin{abstract}
This research is an inquiry in to the concept of depression in selected English and Kurdish poems. It is an attempt to determine in which language depression is used more in the selected poems. The reason behind chosen poems is that they contain different expressions of depression used by English and Kurdish poets. The study consists of 9 sections along with the conclusion and the bibliography.

To oxford word power dictionary (204) depression is defined as a feeling of hopeless and unhappiness that stays for a long time. It could be a medical condition and may also have physical symptoms. Due to this, the selected poems have been analyzed. The result has shown that depression expressions are used more in the English language than those of the Kurdish ones.
\end{abstract}

\section{Introduction}

\section{On Defining Depression}

The Oxford English Dictionary defines depression as "a mental condition characterized by severe feelings of hopelessness and inadequacy, typically accompanied by a lack of energy and interest in life." it is a common mental disorder that presents with depressed mood, loss of interest or pleasure, feelings of being guilty or low self-worth, disturbed sleep or losing appetite and low energy. Usually it occurs as a result of adverse life events, such as: losing of an important person, object, relationship or health, but it can also occur due to no obvious reason. These problems can become recurrent and lead to defect in an individual's ability to take care of his or her every day responsibilities. Cesar and Chavoushi (2013:5)
Most people feel depressed when they lose a loved one, getting fired from a job and going through a divorce etc... can lead a person to feel sad, scared, anxious, lonely, or nervous.

Depression is deeper than just sadness. It interferes with daily life and leads to pain to people and everyone who cares about them. It's a common illness, but a very serious one.

The term "depression" often characterizes feelings of being sad, discouraged, hopeless, unmotivated, as well as a general lack of interest or pleasure in life. Passing a case of blues is a term used if these feelings last for a short period of time but it is called a depressive disorder when they last for more than two weeks and 
interfere with regular daily activities WWW.adaa.org (2016:2).

To Eduardo and Bernard (2018:6) the word depression comes from the Latin "depressio" which means sinking. The person feels sunk with a weight on their existence. It is a mood disorder that varies from: normal transient low mood in daily life itself, to clinical syndrome associated with different features from normality.

Depression consists of a disease with painful feelings, bad humor, anguish and panic attacks, performance, tendency to isolation, difficulty to enjoy, hopelessness and negative thoughts, including possible delusions in cases of serious severity.

\section{The ories of Depression}

The newest theories' classification according to Salih (2005:254) includes the following:

a. Behavior theory: According to this theory the depressed people tend to reduce the value of the positive reinforcement and enlarge the depressive accidents which lead to depression.

b. Cognitive theory: Includes Beck's theory which confirms that the reasons of depression are internal, static and general.

c. Psychological dynamic theory: Says that the depressed people unconsciously punish themselves because they feel that their beloved have left them without being able to punish them.

\section{Causes of Depression}

Darton (2012:7-9) states that depression varies very much from person to person and can happen for one or more reasons. Occasionally it may appear for no obvious reason.

\section{Life Events}

In many cases, the first time someone becomes depressed, it has been triggered by an unwelcome or traumatic event, such as being sacked, divorced, or physically assaulted etc...

\section{Loss}

Often depression can also be seen as a result of losing some thing, or the actual death of someone close, a major life change (such as moving house or changing jobs),or simply moving from one phase of life into another, e.g. as you reach retirement, children leave home, or you come to realize that you may never have a family of your own.

It's not just the negative experience that causes the depression, but if also the feelings provoked are not expressed or explored at the time, they fester and contribute towards depression.

\section{Anger}

In some cases some people call depression 'frozen anger'. people may have experienced something which left them feeling angry and helpless, and if they were unable to express their feelings at the time - perhaps because they were children, or their feelings were unacceptable to others the anger becomes internalized and is expressed as depression.

\section{Childhood Experiences}

If you experienced a traumatic event in childhood, or were abused

Physically or emotionally, or were not helped to learn good coping skills

as you grew up, this can leave you less able to cope with difficulties as an adult and you may feel depression.

\section{Physical Conditions}

The following conditions may cause depression, but are sometimes

Overlooked because of the focus on their physical symptoms:

- Conditions affecting the brain and nervous system 
- Hormonal problems, especially thyroid and parathyroid problems;

symptoms relating to the menstrual cycle or the menopause

- Low blood sugar

- Sleep problems.

\section{Side Effects of Medication}

Depression is a side effect of a lot of different medicines; for example,

many people become depressed after a heart attack and taking medicine as a part of treatment.

\section{Diet}

Poor diet and general lack of fitness can both contribute to depression. Evidence suggests that occasionally people become very depressed in response to some specific foods. Such a reaction is very individual, and people are often not aware of the particular food substance or drink that is causing the problem.

\section{Street Drugs and Alcohol}

Some drugs can also make you depressed, especially if used

repeatedly.

\section{Genetics}

Although no specific genes for depression, have been identified, it does seem to run in families to some extent, and some of us are more prone to depression than others. This could also be because we learn behavior and ways of responding from our relatives, as well as inheriting our genes from them.

\section{Chemical Changes in the Brain}

Because antidepressants work by changing brain chemistry, many people have assumed that depression must be caused by changes in brain chemistry that are then 'corrected' by the drugs. Some doctors may tell you that you have a 'chemical imbalance' and need medication to correct

it Darton (2012:7-9).

To Rehm (2010:53) biology represents only one set of causes. Genetics does make some individuals more prone to depression, and changes in brain chemistry and physiology occur in depression clear. Psychology represents a second set of causes. A pessimistic outlook, low self-esteem, and a sense of powerlessness are some of the tendencies that may contribute to depression. Many of these tendencies may be acquired though experiences early in life. The environment, especially the social environment, represents another set of causal factors in depression.

\section{Depression and Anxiety Disorders}

Depression and anxiety disorders are not the same, but people with depression often experience nervousness and problems sleeping and concentrating, and other symptoms similar to an anxiety disorder. It is not uncommon for someone with an anxiety disorder to suffer from depression and vice versa. Nearly one-half of those diagnosed with depression are also diagnosed with an anxiety disorder.

The term "anxiety disorder" includes generalized anxiety disorder (GAD), panic disorder and panic attacks, social anxiety disorder, selective mutism, separation anxiety, and specific phobias are closely related to anxiety disorders, which some may experience at the same time as depression.

Each disorder has its own causes and its own emotional and behavioral symptoms. Many people who develop depression have a history of an anxiety disorder earlier in life. There is no evidence one disorder causes the other, but there is clear evidence that many people suffer from both disorders. The good news is that these disorders are treatable, separately and together.WWW.adaa.org (6). 


\section{Classification of Depression}

To Al-Samarrai (1988:165) there are two major types of depression, the first one is called Neurotic and the second one is psychogenic depression. To him the first is a neurotic reaction with deep sadness, laziness, misery, dissatisfaction, non-taking care of the surrounding and being disable in achieving tasks and assignments. All these happen to the patient while he or she doesn't know the real reason behind.

The reason of the second one belongs to heredity factors and it might results because of psychogenetic or reactive reasons which why it is called psychogenetic or reactive depression. this type disappears when the external reason of it gone.

\section{Depression, Culture and Society}

There is an obvious difference of depression among the various countries. Some relate this different to the different cultures, religions, and societies in these countries. There are in fact some cultures that reflect depression, pain and sadness in its own people as a phenomenon of emotional life of those people. This could be noticed through their poems, music and even their dance. Since human being is regarded as a social unit in every society .So depression exists less in the united societies but it greatly could be found in the separated communities. One of the evidence to prove that is the comparative study about the two close countries to each other Sweden and Norway in which a child is growing up depending on itself due to the culture while strongly with its family in the second. So depression and suicide exist more in the first country and less in the second Kamal(1988:240).

\section{The Samples of the Res earch}

The sample of the study consists of 8 poems in which the first five are English and the others are Kurdish. The reason behind selecting poems from different languages is to find out whether depression expressions exist more in English or Kurdish poems.

Table (1) the Sample of the English Poems

\begin{tabular}{|c|c|c|}
\hline No. & Poems & Poets \\
\hline 1 & $\begin{array}{l}\text { Struggling with } \\
\text { depression }\end{array}$ & Debbie Leads \\
\hline 2 & Ode on Melancholy & John Keats \\
\hline 3 & Aubade & Philips Larkin \\
\hline 4 & $\begin{array}{l}\text { It was not death,for I } \\
\text { stood up }\end{array}$ & $\begin{array}{l}\text { Emily } \\
\text { Dickinson }\end{array}$ \\
\hline
\end{tabular}

Table (2) the Sample of the Kurdish Poems

\begin{tabular}{|c|c|c|}
\hline No. & Poems & Poets \\
\hline 1 & شيوه نى نيشتمان & قانع \\
\hline 2 & به هارى زه رد & هيمن موكريانى \\
\hline 3 & ئهل ى نائوميدى & وه لى ديو انه \\
\hline 4 & عه شره ت هاو اره & يّيره ميرد \\
\hline
\end{tabular}

8. The Strategy of the Analysis

The whole poems will be divided into lines then the depression expressions are presented while the numbers of the lines which contain such expressions are indicated.

8.1 The analysis of poem (1) "Struggling with depression" by Debbie Leads.

The table below shows the frequency of depression expressions in Lead's poem:

\begin{tabular}{l|ll} 
No. & Depression expression & line \\
\hline 1 & struggle & 1 \\
2 & struggle & 5 \\
3 & guilt & 8 \\
4 & leave & 8 \\
5 & worse & 10 \\
6 & sorry & 14 \\
7 & Worst enemy & 15 \\
8 & I'm nothing & 19 \\
9 & nothing I'm & 20 \\
10 & Little energy & 21 \\
& & \\
11 & Stay in bed & 22 \\
12 & I'm made of lead & 24
\end{tabular}




\begin{tabular}{l|lll|ll}
\hline 13 & Wanting to care for me & 26 & 15 & Droop headed flowers & 13 \\
14 & Nothing makes sense & 27 & No. & Depression Expression & Line \\
15 & hard & 28 & 16 & Hides the green hill & 14 \\
16 & poor & 28 & 17 & Sorrow & 15 \\
17 & Cluttered mind & 29 & 18 & Anger & 18 \\
18 & Cluttered thinking & 29 & 19 & Emprison & 19 \\
19 & hard & 30 & 20 & Rave & 19 \\
20 & worry & 32 & 21 & Peerless eyes & 20 \\
21 & Everybody is better than & 33 & 22 & Must die & 21 \\
22 & me & 23 & Adieu & 23 \\
23 & I can't do anything right & 34 & 35 & 24 & aching \\
24 & No confidence & 37 & 25 & Poison & 23 \\
25 & No self-esteem & 37 & 26 & Melancholy \\
26 & Everybody else is right & 38 & & & 24 \\
27 & My mind is to be a fool & 39 & 27 & None save & 26 \\
28 & problems & 41 & 28 & Burst & 27 \\
29 & A heavy vice & 42 & 29 & Sadness & 28 \\
30 & Living seems like a roll & 44 & 30 & Hung & 29 \\
& of dice & & & & 30 \\
& & & &
\end{tabular}

8.2 The analysis of poem (2) " Ode on Melancholy" by John Keats.

The table below shows the frequency of depression expressions in Keats's poem:

\begin{tabular}{l|ll} 
No. & Depression expression & line \\
\hline 1 & Wolf's bane & 2 \\
2 & poisonous & 2 \\
3 & suffer & 3 \\
4 & pale & 3 \\
5 & nightshade & 4 \\
6 & beetle & 6 \\
7 & death & 6 \\
8 & mournful & 7 \\
9 & Owl & 7 \\
10 & Sorrow's mysteries & 8 \\
& & \\
11 & Drown & 10 \\
12 & Anguish of the soul & 10 \\
13 & Melancholy & 11 \\
14 & Weeping cloud & 12
\end{tabular}

8.3 The analysis of poem (3) " Aubade" by Philips Larkin.

The table below shows the frequency of depression expressions in Larkin's poem:

\begin{tabular}{l|ll} 
No. & Depression expression & line \\
\hline 1 & I work all day & 1 \\
2 & Soundless dark & 2 \\
3 & Unresting death & 5 \\
4 & die & 7 \\
5 & Arid & 8 \\
6 & Dread & 8 \\
7 & Of dying & 9 \\
8 & Dead & 9 \\
9 & Horrify & 10 \\
10 & Remorse & 11 \\
& & \\
11 & The good not down & 12 \\
& & \\
12 & The love not given & 12 \\
13 & Wretchedly & 5 \\
14 & Wrong beginning & 15
\end{tabular}




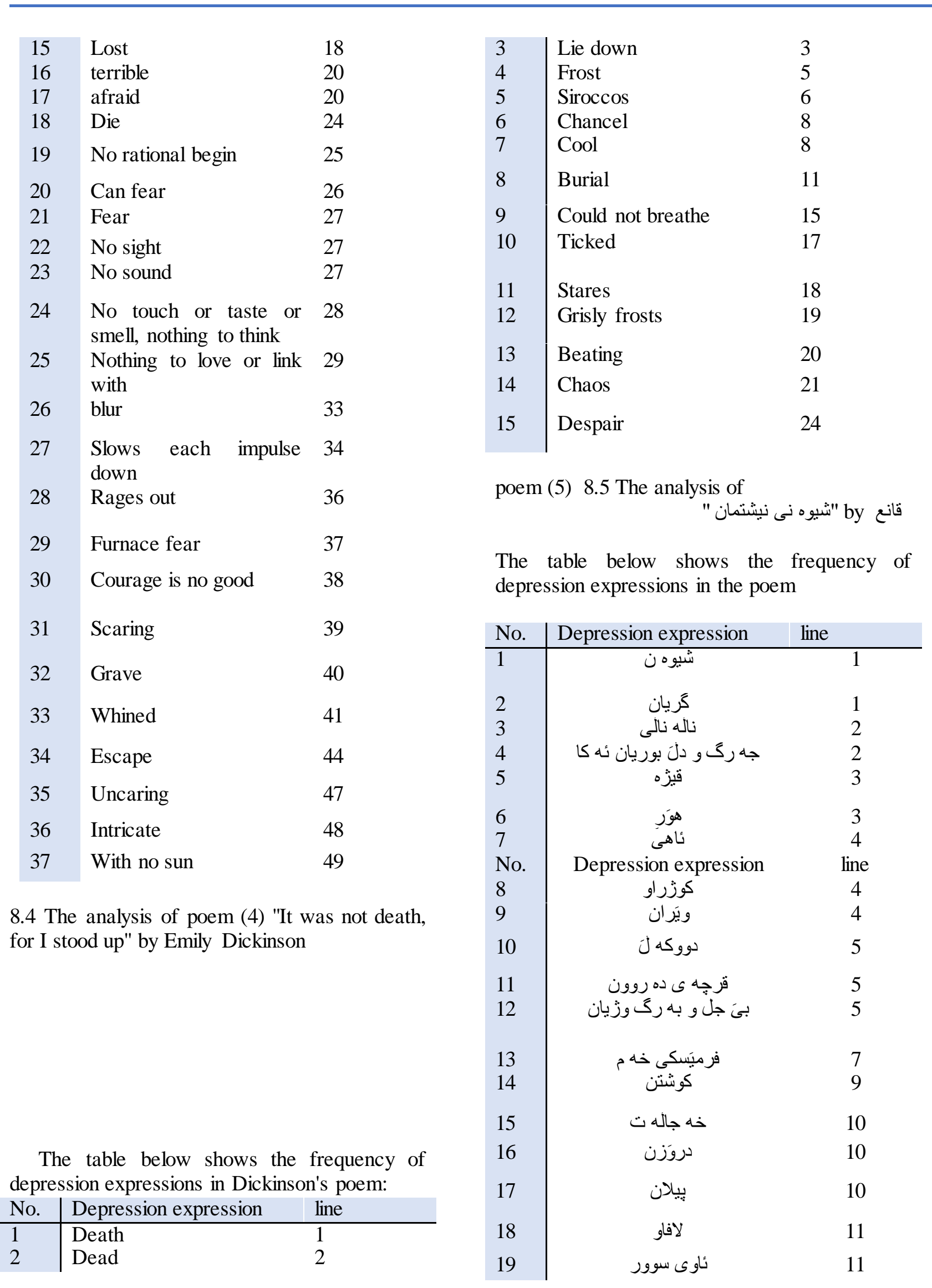




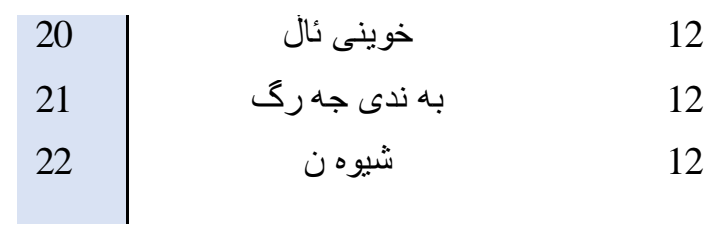

8.6 The analysis of poem (6)

$$
\text { " به هارى زهرد" by هيمن موكريانى. }
$$

The table below shows the frequency of depression expressions in the poem:

\begin{tabular}{|c|c|c|}
\hline No. & Depression expression & line \\
\hline 1 & L ده & 1 \\
\hline 2 & ده رد & 1 \\
\hline 3 & دروَ & 2 \\
\hline 4 & ل ل حززمن & 2 \\
\hline 5 & نامه رد & 2 \\
\hline 6 & زه ردايى & 3 \\
\hline 7 & زهرد & 4 \\
\hline 8 & سكل & 5 \\
\hline 9 & 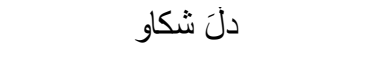 & 5 \\
\hline 10 & فرميَسك & 6 \\
\hline No. & Depression expression & line \\
\hline 11 & خوناو & 6 \\
\hline 12 & و واوه بلا & 7 \\
\hline 13 & شيوه ن & 7 \\
\hline 14 & شينحيَرِ & 8 \\
\hline 15 & جه لاد & 10 \\
\hline 16 & 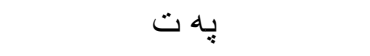 & 10 \\
\hline 17 & 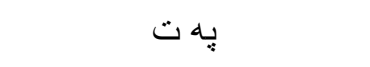 & 11 \\
\hline 18 & 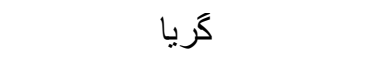 & 13 \\
\hline 19 & به ستر ابوو & 14 \\
\hline 20 & له زير خاكا & 16 \\
\hline 21 & توَر اوى & 17 \\
\hline 22 & ر ره شتر & 18 \\
\hline
\end{tabular}

8.7 The analysis of poem (7)

$$
\text { وه لى ديو انه by "ئه ى نائو ميدى" }
$$

The table below shows the frequency of

\begin{tabular}{|c|c|c|}
\hline No. & Depression expression & line \\
\hline 1 & نائو ميَّاى & 1 \\
\hline 2 & نائو ميَّىى & 1 \\
\hline 3 & ره نجه رويى & 2 \\
\hline 4 & نائو ميَّدى & 2 \\
\hline 5 & ريوزَى رهـ ش & 3 \\
\hline 6 & ده رد & 4 \\
\hline 7 & جوَلَ & 5 \\
\hline 8 & داماو & 7 \\
\hline 9 & يه بروبالَ سوتاوو & 8 \\
\hline 10 & جَوَلَ & 11 \\
\hline 11 & 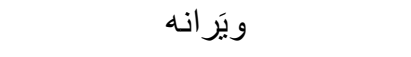 & 11 \\
\hline 12 & 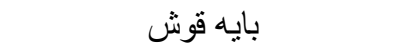 & 12 \\
\hline 13 & نه مابوو ده نحكى هه ياهو & 13 \\
\hline 14 & بى خشيه & 14 \\
\hline No. & Depression expression & line \\
\hline 15 & سامناك & 14 \\
\hline 16 & 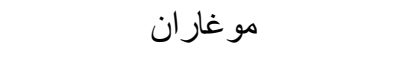 & 14 \\
\hline 17 & بايه قوش & 15 \\
\hline 18 & هاو ده رد & 15 \\
\hline 19 & ل ده رد & 15 \\
\hline 20 & هل ناسه ى سه رد & 16 \\
\hline 21 & 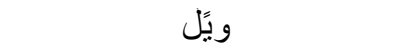 & 17 \\
\hline 22 & 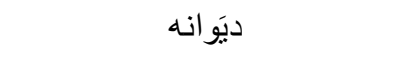 & 17 \\
\hline 23 & ريسوا & 18 \\
\hline 24 & يـه ِِويوَ سوتاوو & 19 \\
\hline 25 & له خيَلَ جََ ماو & 19 \\
\hline 26 & تيرى عه شقى شه م له جه ركى & 20 \\
\hline 27 & بايه قوش داوم & 21 \\
\hline 28 & 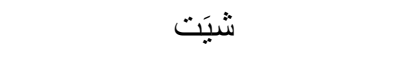 & 21 \\
\hline 29 & سـه وداسه ر & 21 \\
\hline 30 & ريسواى زه مانه & 22 \\
\hline 31 & ويًّلى ده شت و دهر & 22 \\
\hline 32 & بو من جََ ى جوَل ما & 24 \\
\hline 33 & بوَ نوَش نئاخ و داخ & 24 \\
\hline 34 & شومى جاره م & 25 \\
\hline
\end{tabular}
depression expressions in the poem: 


\begin{tabular}{|c|c|}
\hline 35 & نائو ميَدى \\
\hline 36 & سه ودامه وه \\
\hline 37 & ئاخ \\
\hline 38 & جه وتى زه مانه \\
\hline 38 & ويرَانه \\
\hline
\end{tabular}

8.8 The analysis of poem (8)

$$
\text { بيره ميرد by "عه شره ت هلواره" }
$$

The table below shows the frequency of depression expressions in the poem:

\begin{tabular}{|c|c|c|}
\hline No. & Depression expression & line \\
\hline 1 & هاو اره & 1 \\
\hline 2 & هاو اره & 1 \\
\hline 3 & ئاو بـَ بواره & 2 \\
\hline 4 & ريَم نيه & 3 \\
\hline 5 & يليرم & 4 \\
\hline 6 & ئه كهو وم & 4 \\
\hline 7 & كه وتووم & 5 \\
\hline 8 & د ده رده وه & 5 \\
\hline 9 & يُيَشَى دورى & 6 \\
\hline 10 & ئاهى سه رده وه & 6 \\
\hline 11 & دكتورَ & 7 \\
\hline 12 & ئ ئاهم & 8 \\
\hline 13 & ده وران وه ركَهريَ & 8 \\
\hline 14 & وه ركه يريَ & 9 \\
\hline 15 & وه رگهـرين & 9 \\
\hline 16 & زرمه ى تؤب & 10 \\
\hline 17 & تئاو اتم نابيَ & 12 \\
\hline 18 & ته لقينم & 13 \\
\hline 19 & مردى & 14 \\
\hline
\end{tabular}

\section{Conclusions and Results}

Though both Kurdish \& English are two different languages ,but it seems that the number of the depression expression and the average of both languages are not different to great extent yet not the same. Statistically, the study displays that depression expressions have been used 112 (one hundred and twelve) times in the four selected English poems and 101 (one hundred and one) times in the Kurdish ones, this means that the total number of such expressions in the both English and Kurdish poems is 213 (two hundred and thirteen times), so the percentage of the English poems is $52,5 \%$ while that of the Kurdish constitutes $47,417 \%$. It concluded that in according with the study depression expressions are used more in English poems than in Kurdish ones.

\section{References}

English Sources

1. -Baym,Nina(2003).The Norton Analogy of American Literature Vol. c 6th .US

2. -Cesar,Julisca \&Chavoushi,Faraz (2013).Priority medicine for Europe and the world" a public Health Approach to innovation".

3. -Darton,Katherine Depression. London.

4. -Eduardo,Jose \&Bernand,Rondon (2018) Depression: A Review of its Definition Article Vol.5 issued in 1-2018 Venezuela.US.

5. -Ferguson,Margret et.al (2005)5th The Norton Analogy of Poetry.US.

6. -Greenblatt,Stephen(2012) The Norton Analogy of American Literature. Vol. F 9th .US.

7. -Rehm,P.Lynn (2010).Depression. Hogrefe, US.

8. -Oxford wordpower Dictionary. Oxford University

Electronic Sites:

1. -Online ADAA.Org.2016

2. -WWW.Family friendpoems.com

$$
\begin{aligned}
& \text { سهارجاوه كوردييه كان: }
\end{aligned}
$$

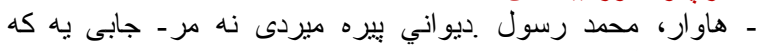

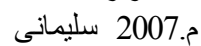

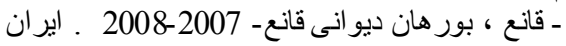

$$
\begin{aligned}
& \text { - رازى. ديو انى وه هون لى ديو انه جانع - }
\end{aligned}
$$

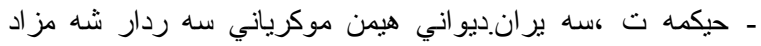

$$
\begin{aligned}
& \text { 2005. عير اق تاق } \\
& \text { المصنادر العربيه } \\
& \text { 1. الدكتور السامر ائى، هاشم.المدخل في علم النفس. كليه التربيه }
\end{aligned}
$$

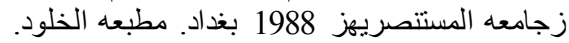

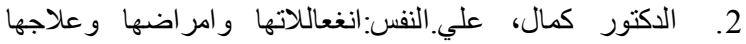

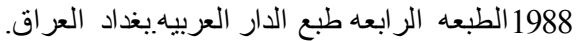

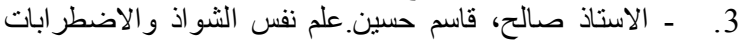

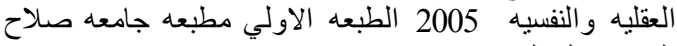

$$
\begin{aligned}
& \text { الدين اربيل العر اق بغداد. }
\end{aligned}
$$

